\title{
In vitro evaluations of cytotoxicity of Abelmoschus esculentus L., Asparagus aphyllus L. and Crataegus azarolus $L$. extracts and their effects on GLUT4 membrane translocation on L6 muscle cells and blood glucose levels in mice
} \author{
AlArda $^{1}$ and Hilal Zaid ${ }^{1,2}$ \\ ${ }^{1}$ Faculty of Arts and Sciences, Arab American University Jenin, P.O Box 240, Jenin, Palestine. \\ ${ }^{2}$ Qasemi Research Center- Al-Qasemi Academy, P.O Box 124, Baqa El-Gharbia 30100, Israel. \\ ${ }^{3}$ Physiology-Pharmacology, University of Fez, P.O. Box 1796 Fez Atlas, Fez, Morocco. \\ ${ }^{4}$ Beleafe Ltd, P.O. Box 2205, Kfar kana, Galilee 16930, Israel. \\ ${ }^{5}$ Shoubak University College, Al-Balqa' Applied University, Al-Salt 19117, Jordan.
}

Abdalsalam Kmail ${ }^{1 *}$, Bashar Saad ${ }^{1,2 *}$, Badiaa Lyoussi ${ }^{3}$, Omar Said ${ }^{4}$, Muhammad Sanad Abu Darwish $^{5}$, Sleman Kadan ${ }^{2}$, Shahd Sammar ${ }^{1}$, Haneen Qalalweh ${ }^{1}$, Raghad ALbzoor ${ }^{1}$, Mahmod

Accepted 25 February, 2019

\begin{abstract}
Despite the enormous achievements in the development of conventional drugs, herbal-based medicines are still a common practice for the prevention/treatment of diabetes and its related complications. Asparagus aphyllus L. (AA), Abelmoschus esculentus L. (AE) and Crataegus azarolus L. (CA) are recommended in the Greco-Arab traditional medicine for the prevention and treatment of diabetes. The purpose of this study was to evaluate the hypoglycemic effects of ethanolic extracts of these plants in high fat (HF)-induced diabetes in male C57BL/6J mice. Animals were divided into nine groups (four mice per a cage) and treated orally with drinking water without (control group) or with one of the extracts at 50 or $100 \mathrm{mg}$ extract $/ \mathrm{kg} / \mathrm{day}$ (treated groups 2-9) for four weeks. Treatment with AA and AE extracts (100 mg/kg/day of each) for 18 days significantly reduced the blood glucose levels by 33 and $29 \%$ compared to control mice, respectievly. CA (both $50 \mathrm{mg} / \mathrm{kg} / \mathrm{day}$ and $100 \mathrm{mg} / \mathrm{kg} /$ day) failed to affect glucose concentration in mice blood throughout the study period. The effects of the plant extracts on glucose transporter-4 (GLUT4) translocation to the plasma membrane was tested in L6 muscle cells, stablely expressing myc epitope at the glucose transporter-4 (L6-GLUT4myc). Exposing of these cells to AA and AE extracts (63 $\mu \mathrm{g} / \mathrm{ml}$ ) led to a significant gain (by about 20\%) in GLUT4 on their plasma membranes at non-cytotoxic concentrations as measured with MTT assay where no significat reduction in cell viability were observed up to $250 \mu \mathrm{g} / \mathrm{ml}$. CA failed to increase the GLUT4 translocation. These findings indicate that the observed hypoglycemic properties of these plants are mediated, at least partially, through regulating GLUT4 translocation.
\end{abstract}

Keywords: Herbal-based medicines, Type 2 diabetes, glucose transporter-4, Abelmoschus esculentus, Asparagus aphyllus, Crataegus azarolus.

*Corresponding authors: E-mail: abdalsalam.kmail@aaup.edu, bashar.saad@aaup.edu.

\section{INTRODUCTION}

Diabetes is a metabolic disorder that results from insulin resistance or the insufficient insulin production, ultimately causing hyperglycemia. Compared to the global prevalence of diabetes the Middle East show the very 
high numbers where 15.2 million subjects were diagnosed as diabetic in 2000 and the number is expected to reach about 42.6 millions by 2030 (Saad et al., 2012). This rapid increase is due to population growth, aging, urbanization, increasing prevalence of obesity, and reduced physical activity.

Insulin is secreted by pancreatic $\beta$-cells to the blood. The mechanisms through which insulin functions to control blood glucose is through maintaining an equilibrium in between glucose production in the liver, or glucose appearance and glucose uptake by glucose transporter type 4 (GLUT4) of muscle and adipose cells, in the process of glucose clearance (Zaid et al., 2008; Victoria et al., 2018). Insulin initiates GLUT4 translocation via the activation of PI3K-Act and Cbl-CAP pathways ( $\mathrm{Li}$ and Zhang, 2007). Malfunction of the GLUT4 translocation was found to cause type 2 diabetes mellitus (T2DM) (Zaid et al., 2008). In T2DM, cells have a diminished capacity to respond to insulin in spite of its presence. Like other types of diabetes, the exact causes are not yet discovered, however, there is no doubt that genetic and epigenetic factors contribute to the reduction in the affinity of insulin receptor (IR) kinase or insulin receptor substrate (IRS) to phosphorylation, and hence diminishing GLUT4 recruitment to the plasma membrane (Fasshauer et al., 2000).

Nature is the best source for medicines as it has been optimized to interact optimally with the biological systems through a long natural selection process. Indeed, natural products have been a source of therapeutics since ancient times, and during the past century, many drugs have been developed from natural sources (Zaid et al., 2015; Saad et al., 2017). Asparagus aphyllus L. (AA), Crataegus azarolus $\mathrm{L}$. (CA) and Abelmoschus esculentus $\mathrm{L}$. $(\mathrm{AE})$ are widely used in the Mediterranean region as traditional remedies. Crataegus species has been utilized for a long time as a traditional medicine for the treatment of inflammation and gastrointestinal ailments. The plant was found to possess antiproliferative activity on different cancerous human cell lines (Kmail et al., 2015). CA has been used in the Greco-Arab traditional medicine to treat cardiovascular diseases, sexual weakness, cancer and diabetes (Saad and Said, 2011). Additionally, it has been used as an antioxidant, hypolipidemic, an antimicrobial agent and a stimulant for digestion and blood circulation (Popovic-Milenkovic et al., 2014; Shin et al., 2013). Phenolic compounds namely, chlorogenic acid, (-)epicatechin, hyperoside, isoquercitrin, quercetin, rutin, spiraeoside, and the dimer procyanidin $b_{2}$ detected in the Tunisian CA are responsible for the antioxidant capacity of this species (Bahri-Sahloul et al., 2009). AA is used in traditional Greco-Arab and Islamic medicine to treat various diseases such as diarrhea and dysentery (Saad and Said, 2011). Recently we have reported that water/ethanol extracts of $\mathrm{AA}$ and $\mathrm{CA}$ modulated the production of pro-inflammatory cytokines (TNF- $\alpha$ and IL6) and anti-inflammatory cytokines (IL-10) in LPS- activated THP-1-derived macrophages in monoculture as well as in co-culture systems with L6 cells (Kmail et al., 2017). The main constituents of Asparagus are steroidal saponins, vitamins (A, B1, B2, C and E), amino acids (mainly: asparagine, arginine and tyrosine), crucial atoms ( $\mathrm{Mg}, \mathrm{P}, \mathrm{Ca}$ and $\mathrm{Fe}$ ), folic acid, essential oils, flavonoids (kaempferol, quercetin, and rutin), resin, and tannin (Negi et al., 2010). AE is an annual herb that is widely cultivated for the green fruits that have slimy mucilage. AE is used in traditional Greco-Arab and Islamic medicine to treat diseases of the digestive system (Saad and Said, 2011). Obese rats treated with $A E$ extracts lost a significant weight (Huang et al., 2017). Moreover, AE possess a strong antioxidant activity (Kmail et al., 2017).

The present study examines the potential hypoglycemic activity of $A A, C A$ and $A E$ ethanolic extracts on high fat diet (HFD)-induced diabetic C57BL/6J mice and L6 muscle cells.

\section{MATERIALS AND METHODS}

\section{Plant collection}

Plants used in the study (Table 1) were collected from the hills of the West Bank during the spring and summer terms. An authorized botanist confirmed the botanical identity of the plant specimen. The plants were cleaned and dried for 7 to 10 days in the shade at the obtained surrounding temperatures, then ground and stored in cloth bags at $5^{\circ} \mathrm{C}$. They were then transferred to the laboratory for the preparation of plant extracts.

\section{Plant extract preparation}

Fifteen grams of the hand grinded plant material were added to 100 $\mathrm{ml}$ of $50 \%$ ethanol in double distilled water and boiled at $92^{\circ} \mathrm{C}$ for 10 min under stirring. Extract supernatants obtained were passed through a $0.2 \mu \mathrm{m}$ filter, and stored at $-80^{\circ} \mathrm{C}$ (Kmail et al., 2015).

\section{L6 cells used in vitro}

Rat muscle cell line (L6) expressing c-myc epitope-tagged GLUT4; L6-GLUT4myc; (a kind gift from Dr. Amira Klip, the Hospital for Sick Children, Toronto) were used as a model for tracking GLUT4 translocation to the plasma membrane. They were grown under an atmosphere of $95 \%$ air and $5 \% \mathrm{CO}_{2}$ in alpha minimal essential media ( $\alpha$-MEM) supplemented with $10 \%$ fetal calf serum (FCS), 1 $\mathrm{mM} \mathrm{L}$-glutamine, $100 \mathrm{U} / \mathrm{ml}$ penicillin and $0.1 \mathrm{mg} / \mathrm{ml}$ streptomycin.

\section{Animal care}

C57BL/6J inbred mice are a sub-strain of mice that was developed in 1948 at the Jackson Laboratory from C57BL/6 parents at F22 (Mekada et al., 2009). These mice are known to develop obesity and diabetes type 2 if exposed to high fat diets but return to normal status when the food is substituted with low fat diet (Parekh et al., 1998). They were purchased from (ENVIGO, USA). After arrival, male C57BL/6J mice were separated by sex into five per cage for two weeks to adapt to the new environment and get sexually mature for mating. The mice were supplied with the gray normal diet (ND). Temperature was adjusted at $24^{\circ} \mathrm{C}$ with $12-12 \mathrm{~h}$ lightdark cycles. 
Table 1. Ethnobotanical data, collection time and parts used of the three medicinal plants used in the study.

\begin{tabular}{llcl}
\hline Plant species & Family & Time of collection & Used parts \\
\hline Asparagus aphyllus L. (AA) & Asparagaceae & $\begin{array}{c}\text { April } \\
1^{\text {st }} \text { week }\end{array}$ & Aerial \\
Abelmoschus esculentu L. Moench (AE) & Malvaceae & $\begin{array}{c}\text { May } \\
\text { th }\end{array}$ & Fruits \\
Crataegus azarolus L. (CA) & Rosaceae & July & Leaves \\
\hline
\end{tabular}

\section{Animal experiment}

When the mice males reached 6-7 weeks old, they were supplied with the induced obesity high fat diet (HFD), (coded TD.06414, ENVIGO) composed of $34.3 \%$ fat with energy of $(5.1 \mathrm{Kcal} / \mathrm{g})$. After about 6 weeks, blood glucose levels were elevated from $100 \mathrm{mg} / \mathrm{dl}$ (normal level) to 170 to $200 \mathrm{mg} / \mathrm{dl}$ (diabetic levels). One week prior to the tests, the diabetic animals were divided randomly into nine groups (four mice per a cage) and treated orally with drinking water without (control) or with one of the extracts at 50 or $100 \mathrm{mg}$ extract $/ \mathrm{kg} /$ day for four weeks. Blood was taken from the tail veins of four-hour fasting mice and sugar levels were measured using the ACCU-CHEK Blood Glucose Meter (Roche, Germany). Water intake and body weight were recorded every $48 \mathrm{~h}$. Ethics approval was obtained from Sidi Mohamed Ben Abdallah University Mohammed in Fez, under the responsibility of the Animal Facility and the Laboratory of Physiology-Pharmacology \& Environmental Health at the Faculty of Science Dhar Mahraz of Fez (PPSE01DEC2016). The experiments were conducted in accordance with the accepted principles outlined in the "Guide for the Care and Use of Laboratory Animals" prepared by the National Academy of Sciences and published by the National Institutes of Health and all efforts were made to minimize animal suffering and the number of animals used.

\section{Colorimetric assay of surface GLUT4myc}

Quiescent L6-GLUT4myc cells grown in 24-well plates for one day followed by addition of the plant extracts at 62.5 and $125 \mu \mathrm{g} / \mathrm{ml}$ for $24 \mathrm{~h}$ and serum-starved for $3 \mathrm{~h}$ were treated without or with $100 \mathrm{nM}$ insulin for $20 \mathrm{~min}$. Surface myc tagged GLUT4 was measured in intact, non-permeabilized cells as previously described (Kaadan et al., 2018). Briefly, the cells were washed twice with cooled phosphate buffered saline (PBS) and fixed in 3\% paraformaldehyde in PBS for $10 \mathrm{~min}$. Cells were then blocked with $3 \%$ goat serum in PBS at $4^{\circ} \mathrm{C}$ for $10 \mathrm{~min}$. Primary antibodies (anti-c-myc, Sigma) were then added into the cultures at a dilution of 1:200 and maintained for $1 \mathrm{~h}$ at $4^{\circ} \mathrm{C}$. Cells were then thoroughly washed with PBS. After that, peroxidase-conjugated rabbit anti-mouse $\lg G(1: 1000)$ was introduced. After $1 \mathrm{~h}$ at $4^{\circ} \mathrm{C}$, cells were extensively washed, and 1 $\mathrm{ml}$ o-phenylenediamine dihydrochloride reagent was added to each well. The colorimetric reaction was stopped by adding $0.25 \mathrm{ml}$ of 3 $\mathrm{N} \mathrm{HCl}$ for $10 \mathrm{~min}$ at room temperature. The supernatants were then collected, and the optical absorbance measured at $492 \mathrm{~nm}$. Background absorbance obtained in the absence of anti-myc antibody was subtracted from all values.

\section{MTT assay}

The tetrazolium dye, MTT, is widely used to assess the viability and/or the metabolic state of the cells. This colorimetric assay is based on the conversion of the yellow tetrazolium bromide (MTT) to the purple formazan derivative by mitochondrial succinate dehydrogenase in viable cells. MTT viability assay was carried out as described by (Kaadan et al., 2013). Briefly, twenty-four hours after cell seeding, L6 cells were exposed to varying concentrations of the plant extracts $(0$ to $1000 \mu \mathrm{g} / \mathrm{ml})$ for $24 \mathrm{~h}$ at $37^{\circ} \mathrm{C}$. Following the removal of the media from the wells, cells were washed in PBS and incubated in a serum-free medium. MTT $(0.5 \mathrm{mg} / \mathrm{ml})$ was then added to each well $(100 \mu \mathrm{l})$ and incubated for further four hours in the dark. The cells were then washed and incubated for 15 minutes with $100 \mu \mathrm{l}$ of acidic isopropanol $(0.08 \mathrm{~N} \mathrm{HCl})$ to dissolve the formazan crystals occluded in the mitochondria. The absorbance of the MTT formazan was determined at $570 \mathrm{~nm}$ in the ELISA reader. Cell viability was defined as the ratio (expressed as a percentage) of absorbance of treated cells to untreated cells.

\section{Statistical analysis}

Data was obtained from three independent experiments, and represented as mean $\pm S D$. Nonlinear best fit was plotted with mean \pm SD. Throughout the analysis, $P<0.05$ was considered statistically significant. Error limits cited and error bars plotted represent simple standard deviations of the mean. When comparing different samples, results were considered to be statistically significant when $\mathrm{P}<0.05$ (Student's t test for unpaired samples).

\section{RESULTS}

\section{Assessments of hypogycemic effects of the three plant extracts in C57BL/6J mice}

The hypogycemic effects of $A A, A E$ and $C A$ extracts were tested in C57BL/6J diabetic mice model. None-diabetic mice had a nomal level of blood glucose (about 100 $\mathrm{mg} / \mathrm{dl}$ ) while high fat fed mice exhibited 170 to $200 \mathrm{mg} / \mathrm{dl}$. No significant change in blood glucose levels was observed in the untreated diabetic group throughout the study.

\section{AA extracts}

Mice blood glucose levels were decreased after the treatment with AA extracts at both 50 and $100 \mathrm{mg} / \mathrm{kg} /$ day. Figure 1A shows significant hypoglycemic effects 


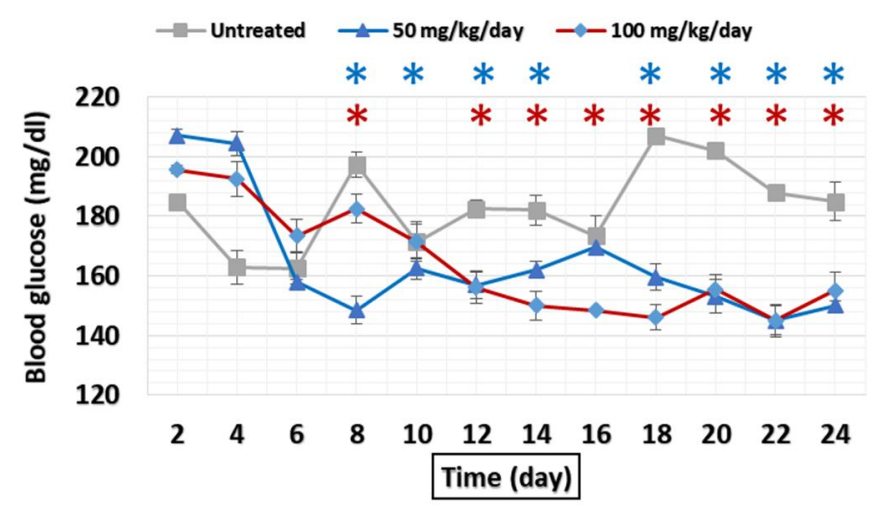

A

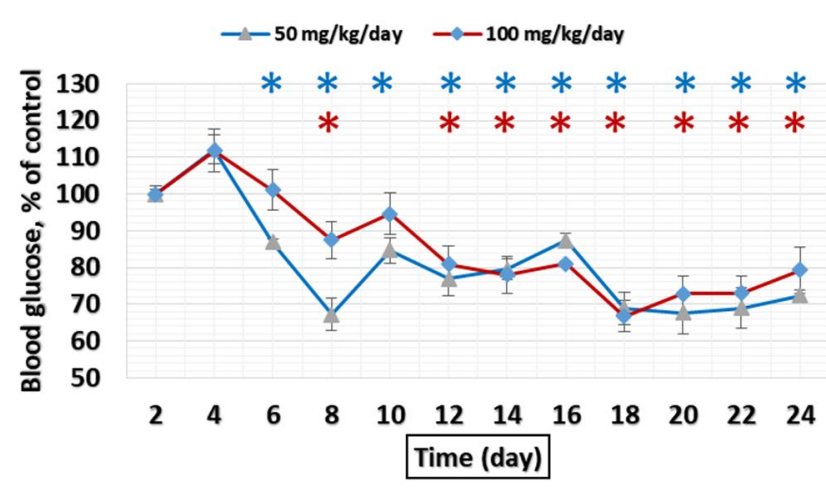

B

Figure 1. The effect of $A A$ (50 and $100 \mathrm{mg} / \mathrm{kg} /$ day) on mice blood glucose levels in $\mathrm{mg} / \mathrm{dl}(\mathrm{A})$ and as $\%$ of control (B). Untreated, diabetic high fat fed mice provided with normal sterile water; treated, diabetic high fat fed mice provided with sterile AA extract in the drinking water.

especially six days after treatment with $50 \mathrm{mg} / \mathrm{kg} / \mathrm{day}$. Serum glucose levels decreased from 207 to $158 \mathrm{mg} / \mathrm{dl}$, followed by a fluctuation in glucose concentration until the $18^{\text {th }}$ day of treatment. Between the $20^{\text {th }}$ and $24^{\text {th }}$ days of treatment (marking the end of the experiment), a stronger decrease in blood glucose was noticed $(150 \mathrm{mg} / \mathrm{dl})$ (Figure 1A). Treatment with AA extracts at $100 \mathrm{mg} / \mathrm{kg} /$ day induced similar significant downregulation of glucose at the $6^{\text {th }}$ day post treatment, where glucose levels decreased from 196 to $173 \mathrm{mg} / \mathrm{dl}$. Fluctuations around this reading lasted just for the next four days up to the $10^{\text {th }}$ day of treatment. Between the $10^{\text {th }}$ and $20^{\text {th }}$ days, glucose levels decreased to reach $146 \mathrm{mg} / \mathrm{dl}$. At the end of the experiment, readings got stable around $155 \mathrm{mg} / \mathrm{dl}$ (Figure 1A). These results indicate that $A A$ extracts can effectively lower the mice blood glucose by 40 to 60 $\mathrm{mg} / \mathrm{dl} \mathrm{(20} \mathrm{to} 30 \%$ decrease compared to control, Figure 1B).

\section{$A E$ extracts}

$A E$ extracts induced hypoglycemic effects at 50 $\mathrm{mg} / \mathrm{kg} /$ day (Figure 2A). Glucose levels ranged between 201 and $203 \mathrm{mg} / \mathrm{dl}$ at the end of the study period, which is comparable with the progression in blood glucose levels in the untreated group. Nonetheless, treatment of the mice with extracts of $100 \mathrm{mg} / \mathrm{kg} /$ day resulted in a slight decrease in serum glucose levels, starting from the $8^{\text {th }}$ day of treatment. Significant serum glucose reduction was seen at the $12^{\text {th }}$ day of treatment, where blood glucose levels reached $158 \mathrm{mg} / \mathrm{dl}$ (initial serum glucose levels before treatment were $208 \mathrm{mg} / \mathrm{dl}$ ). Readings dynamically fluctuated between the $12^{\text {th }}$ and the $16^{\text {th }}$ days, until they reached stable values at the end of the study period $(166 \mathrm{mg} / \mathrm{dl}$ ) (Figure $2 \mathrm{~A})$. These results indicate that $A E$ can effectively lower the levels of blood glucose in mice at nontoxic concentrations of over than
$42 \mathrm{mg} / \mathrm{dl}$ in a dose-dependent manner.

\section{CA extracts}

Treatment with CA extracts (both $50 \mathrm{mg} / \mathrm{kg} /$ day and 100 $\mathrm{mg} / \mathrm{kg} /$ day failed to reduce glucose levels in mice blood throughout the study period. The results were similar for the treated and untreated group (Figure $3 \mathrm{~A}$ ). Using both 50 and $100 \mathrm{mg} / \mathrm{kg} /$ day of the 3 plant extracts showed no toxicity by observing the mass and behavior of the animals (data not shown).

\section{In vitro assessments of cytotoxic effects of plant extracts on L6 muscle cells}

Results obtained indicate that AA extracts exhibited no sign of any cytotoxic effects as measured with MTT test at all tested concentrations (up to $1000 \mu \mathrm{g} / \mathrm{ml}$ ) tested in L6 cells (Figure 4). AE extracts and CA extracts inhibited cell viability at concentrations higher than $125 \mu \mathrm{g} / \mathrm{ml}$ tested in L6 cells (Figure 4).

\section{In vitro assessment of GLUT4 translocation to the plasma membrane}

To examine the effect of the plant extracts on GLUT4 translocation to the plasma membrane in the presence and absence of insulin, L6-GLUT4myc cells were exposed to water/ethanol extracts for $24 \mathrm{~h}$. Figure 5 shows that insulin could stimulate the GLUT4 translocation to the plasma membrane compared to the non-induced cells. In the presence as well as absence of insulin, a dose-dependent increase in GLUT4 translocation was observed when L6 cells treated with the AE extract. At $125 \mu \mathrm{g} / \mathrm{ml}$ GLUT4 translocation to the 


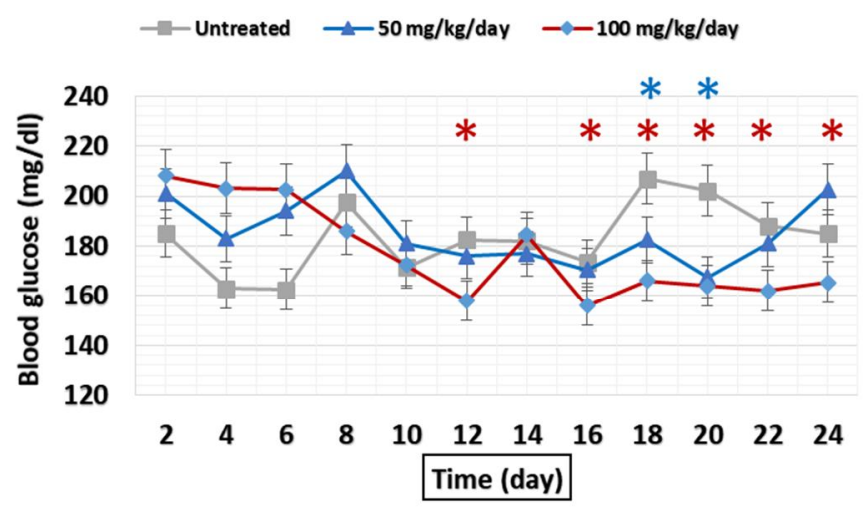

A

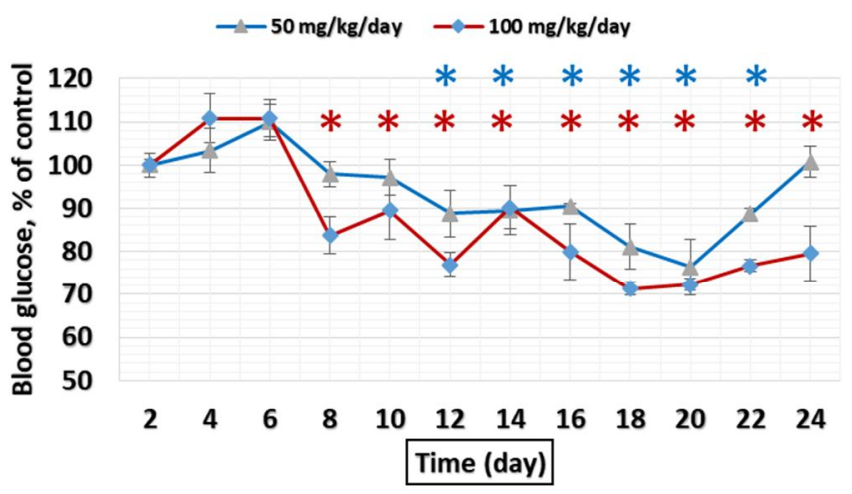

B

Figure 2. The effect of $A E$ (50 and $100 \mathrm{mg} / \mathrm{kg} /$ day) on mice blood glucose levels in $\mathrm{mg} / \mathrm{dl}(\mathrm{A})$ and as \% of control (B). Untreated, diabetic high fat fed mice provided with normal sterile water; treated, diabetic high fat fed mice provided with sterile $A E$ extract in the drinking water.
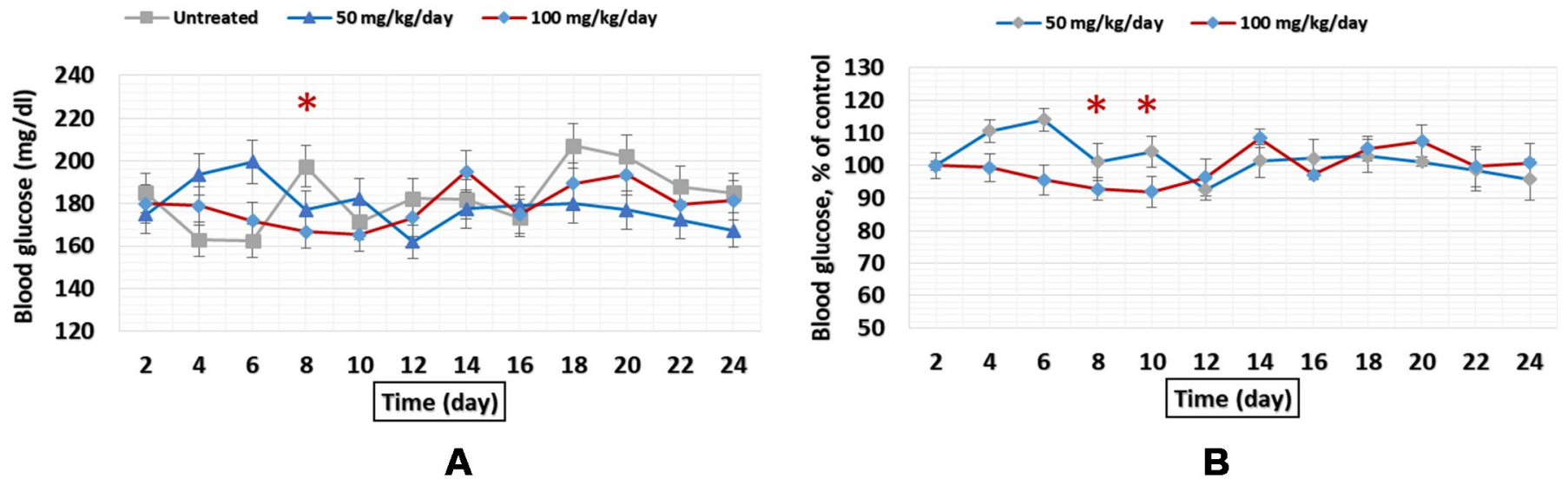

Figure 3. The effect of CA (50 and $100 \mathrm{mg} / \mathrm{kg} / \mathrm{day}$ ) on mice blood glucose levels in $\mathrm{mg} / \mathrm{dl}$ (A) and as \% of control (B). Untreated, diabetic high fat fed mice provided with normal sterile water; treated, diabetic high fat fed mice provided with sterile CA extract in the drinking water.

plasma membrane increased by $14 \%$ in the absence of insulin, and by $19 \%$ in the presence of insulin (Figure $5 \mathrm{~A}$ ).

AA extract at $125 \mu \mathrm{g} / \mathrm{ml}$ increased GLUT4 translocation to the plasma membrane by $24 \%$ in the absence of insulin and by $21 \%$ in the presence of insulin. The increase in the translocation was in a concentrationdependent manner (Figure 5B).

CA extracts induced an inhibition of the GLUT4 translocation by $19 \%$ in the absence of insulin and by $17 \%$ in the presence of insulin (Figure $5 \mathrm{C}$ ).

\section{DISCUSSION}

The diabetic mice were introduced to 0,50 or 100 $\mathrm{mg} / \mathrm{kg} /$ day water/ethanol plant extract. AA extracts were capable to reduce blood glucose levels in mice both at 50 and $100 \mathrm{mg} / \mathrm{kg} / \mathrm{day}$ extract concentrations. Results for the two doses equilibrated the blood glucose concentration by the end of the experiment (with 150 and $155 \mathrm{mg} / \mathrm{dll}$, respectively) (Figure 1). The test on cytotoxicity levels up to $100 \mathrm{mg} / \mathrm{kg} /$ day of the AA extracts showed no toxicity. Similar results published by (Hannan et al., 2012), showed that ethanol extracts of Asparagus racemosus roots can improve glucose transport and insulin action in 3T3-L1 adipocytes. The extracts caused hypoglycemia in both normal and diabetic rats following the ingestion with sucrose. Other studies of the same genus were performed in diabetic Wistar rats. The administration of the methanolic extracts of the seeds of Asparagus officinalis to the diabetic rats caused a decrease of blood glucose in dose- and time-dependent manners. Additionally, the extracts could induce insulin production and improved the functioning of $\beta$-cell (Hafizur et al., 2012). The oral introduction of ethanolic extracts of Asparagus racemosus Willd (Liliaceae) to Wistar rats 


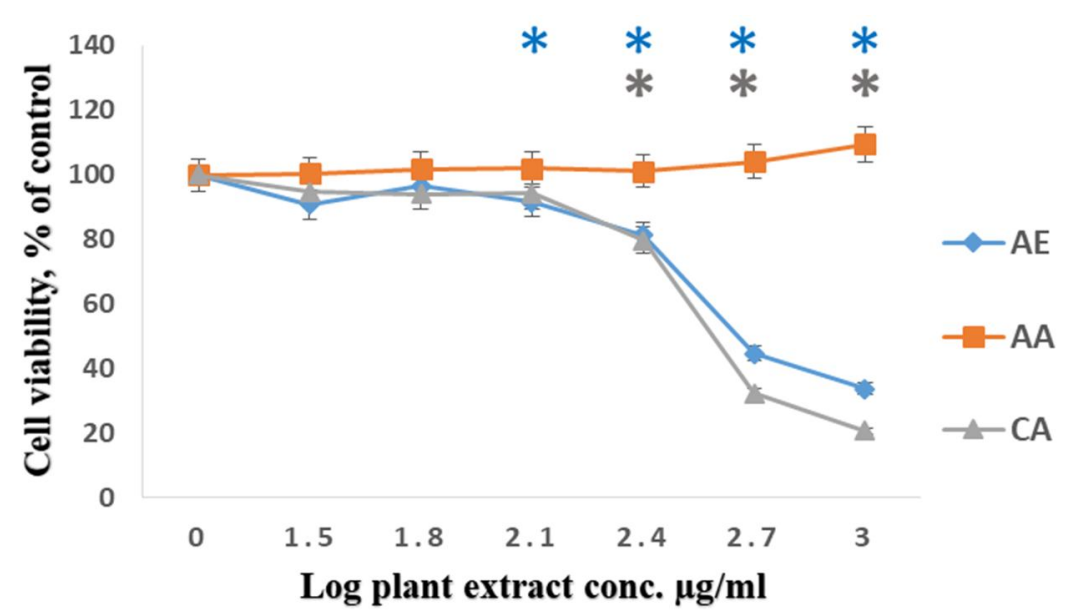

Figure 4. MTT assay of three plant extracts in L6 cells. MTT assay in L6 cells after $24 \mathrm{~h}$ treatment with increased concentrations of extract from AE, AA and $\mathrm{CA}$. The absorbance of the MTT formazan was determined at $570 \mathrm{~nm}$ in an ELISA reader. Cell viability was defined as the absorbance ratio (expressed as a percentage) of plant extracts treated cells relative to untreated cells. Values represent means $\pm \mathrm{SD}\left({ }^{*} P<0.05\right.$ was considered significant compared to control) of three independent experiments carried out in triplicates.

reduced blood glucose levels. Furthermore, the extracts could also lower the synthesis of creatinine, urea nitrogen, total cholesterol and triglyceride (Somania et al., 2012). Treatment of Wistar rats with nontoxic concentrations of Asparagus racemosus extracts induced weight loss and hypoglycaemic and hypolipidaemic properties when compared to the untreated control (Senadheera et al., 2014).

Compared with AA extracts, treatment of mice with $\mathrm{AE}$ extracts was not as effective in reducing blood glucose levels at low concentrations $(50 \mathrm{mg} / \mathrm{kg} /$ day $)$. The hypoglycemic effect was only noticed at $100 \mathrm{mg} / \mathrm{kg} / \mathrm{day}$ dose, which showed an equilibration around $166 \mathrm{mg} / \mathrm{dl}$ in blood glucose levels towards the end of the study (Figure 2). No toxicity was deduced from using $100 \mathrm{mg} / \mathrm{kg} /$ day of the $A E$ extracts showed. Thus, $A E$ is a potential plant that can be used for the treatment of diabetes. Earlier studies have explored the antihyperglycemic effect of the plant at similar and higher doses. Peel and seed powder of $A E$ were found to have antidiabetic effects in vivo by inhibiting superoxide dismutase, chloramphenicol acetyl transferase, glutathione peroxidase and glutathione. The extracts were also found to increase the levels of thiobarbituric acid reactive substances (Sabitha et al., 2012). Peel and seed powder of AE (100 and 200 $\mathrm{mg} / \mathrm{kg} /$ day) administered to rats caused a significant decrease in blood glucose, glycosylated hemoglobin, and serum glutamate-pyruvate transferase levels. The plant was also found to cause an increase in hemoglobin total protein levels (Sabitha et al., 2011).

Unlike the extracts from $A A$ and $A E$, extracts from $C A$ (both $50 \mathrm{mg} / \mathrm{kg} /$ day and $100 \mathrm{mg} / \mathrm{kg} /$ day) did not affect glucose concentration in mice blood throughout the study period for either the treated or untreated groups. Since no toxicity was recorded at $100 \mathrm{mg} / \mathrm{kg} /$ day dose (Figure 3), it is suggested to increase the introduced dose.

In this study, L6 muscle cells were designed to identify the effect of plant extracts on GLUT4 translocation. Before starting these experiments, and in order to use safe extract concentrations that can be used in the experiments that follow, the cytotoxic effects of the three medicinal plants was evaluated in L6 cells (Figure 4). MTT was carried out $24 \mathrm{~h}$ after treatment with increasing concentrations ( 0 to $1000 \mu \mathrm{g} / \mathrm{ml}$ of culture medium) of each extract. The extracts of the three plants $(A A, A E$ and $C A$ ) exhibited no cytotoxic effects up to $125 \mu \mathrm{g} / \mathrm{ml}$. In this regard, cells treated with the three extracts showed the best viability beyond $125 \mu \mathrm{g} / \mathrm{ml}$ concentration.

Translocation of GLUT4 to the plasma membrane is a crucial process mediated in part by insulin, which is responsible for maintaining glucose flow under needs. The effect on GLUT4 translocation was carried out using rat skeletal muscles L6-GLUT4myc cell line. Insulin causes GLUT4 translocation to the surface of myoblasts, where it mediates the increase in glucose loading to the cells for metabolism; what induces a decrease in glucose concentration in blood. GLUT4 membrane translocation process may be impaired in cases of insulin resistance and T2DM. In our study, water/ethanol extracts of the four plants were added separately for $24 \mathrm{~h}$ to L6GLUT4myc cultures. Each extract was applied with or without insulin to the culture (Figure 5). Insulin enhanced GLUT4 translocation to the plasma membrane by 40 to $50 \%$ as reported earlier (Zaid et al., 2009; Kaadan et al., 


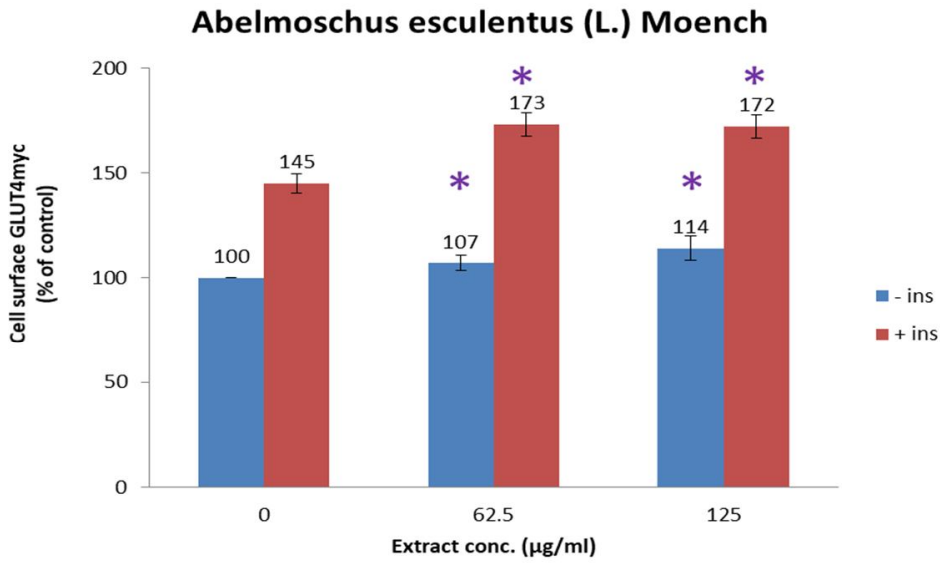

A

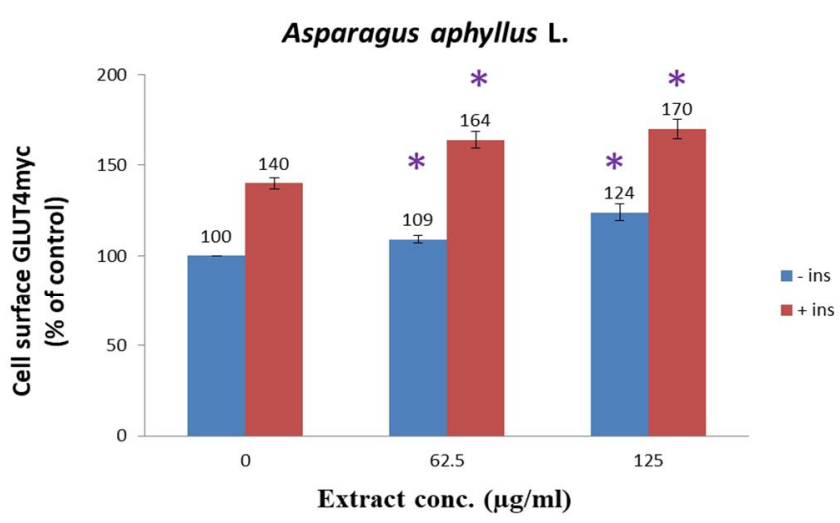

B

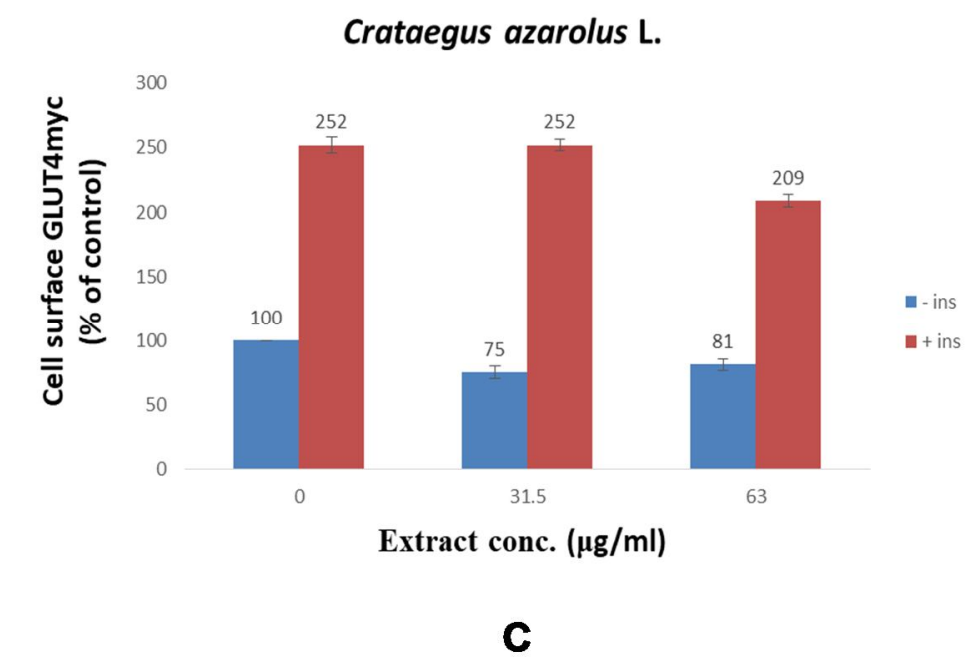

Figure 5. Effect of plants extracts on GLUT4 translocation. L6-GLUT4myc cells were seeded in 24-well plate (100,000 cells/well) and exposed to various extracts for $24 \mathrm{~h}$. Serum depleted cells were treated without or with $100 \mathrm{nM}$ insulin for 20 min at $37^{\circ} \mathrm{C}$ and surface myc-tagged GLUT4 density was quantified using the antibody coupled colorimetric assay. Shown are the means \pm S.E relative to basal untreated cells from three independent experiments (each has three triplicates).

2018). Treatment of L6 cells with $125 \mu \mathrm{g} / \mathrm{ml} \mathrm{AE} \mathrm{extract}$ augmented GLUT4 translocation to the plasma membrane by 14 and $19 \%$ in the absence and presence of insulin respectively, suggesting synergism between $\mathrm{AE}$ extract and insulin. Taken together, these readings with the obtained results in vivo show that $A E$ may downregulate blood glucose in part by improving GLUT4 membrane translocation. Similar results were obtained by applying myricetin, which was extracted from Abelmoschus moschatus, in obese diabetic rat. The plant was found to improve the insulin sensitivity by activating IRS-1-associated PI3-kinase in insulin signaling pathway, as well as improving GLUT4 activity in obese diabetic rats (Liu et al., 2007).

Upon applying AA extract $(62.5 \mu \mathrm{g} / \mathrm{ml}$ and $125 \mu \mathrm{g} / \mathrm{ml})$, GLUT4 translocation to the plasma membrane increased both in the presence and absence of insulin. However, the synergic action was only noticed at the $62.5 \mu \mathrm{g} / \mathrm{ml}$ concentration. Taken together, these readings with the obtained results in vivo, show that AA may downregulate blood glucose by improving GLUT4 membrane translocation at nontoxic concentrations. To the best of our knowledge, this is the first study reporting the mechanism of a potential anti-diabetic activity of the AA.

As the in vivo experiment showed no antihyperglycemic effects of CA extracts, in vitro experiment showed no positive effects of the CA extracts in terms of GLUT4 translocation. Surprisingly, the plant extract reduced GLUT4 translocation both in the presence and absence of insulin. Nonetheless, it seems that insulin effect could antagonize the repression by CA extracts at lower concentrations $(31.5 \mu \mathrm{g} / \mathrm{ml})$. Further investigation is needed to understand the mechanisms behind the inhibitory effect. 


\section{CONCLUSIONS}

Here we present and discuss results obtained in vitro cytotoxic test of water/ethanol extracts $A E, A A$, and $C A$ as well as the effects of these extracts on GLUT4 membrane translocation on L6 muscle cells and blood glucose levels in mice. Treatment with $A A$ and $A E$ extracts significantly reduced the blood glucose levels by $33 \%$ and $29 \%$ compared to control mice, respectievly. CA failed to affect glucose concentration in mice blood throughout the study period. Results of GLUT4 translocation to the plasma membrane could be merged with results obtained in vivo, to indicate that non-toxic concentrations of $A A$ and $A E$ may downregulate blood glucose by improving GLUT4 membrane translocation in a concentration dependent manner at nontoxic concentrations. These experiments are one step away from the identification of novel safe drugs for curing diabetes by medicinal plants. Different experiments should be followed to build a clear picture regarding the mechanisms of action and specific cellular target of the plants extracts.

\section{ACKNOWLEDGMENTS}

This work was supported by AAUJ Research Foundation. We are thankful to Prof. Amira Klip (The Hospital for Sick Children, Toronto, Canada) for providing the L6GLUT4myc cells.

\section{REFERENCES}

Bahri-Sahloul R, Ammar S, Fredj RB, Saguem S, Grec S, Trotin F, Skhiri FH, 2009. Polyphenol contents and antioxidant activities of extracts from flowers of two Crataegus azarolus L. varieties. Pak J Biol Sci, 12: 660-668.

Fasshauer M, Klein J, Ueki K, Kriauciunas KM, Benito M, White MF, Kahn CR, 2000. Essential role of insulin receptor substrate-2 in insulin stimulation of Glut4 translocation and glucose uptake in brown adipocytes. J Biol Chem, 275: 25494-25501.

Hafizur RM, Kabir N, Chishti S, 2012. Asparagus officinalis extract controls blood glucose by improving insulin se4cretion and $\beta$-cell function in streptozotocin-induced type 2 diabetic rats. Br J Nutr, 108: 1586-95.

Hannan JM, Ali L, Khaleque J, Akhter M, Flatt PR, Abdel-Wahab YH, 2012. Antihyperglycaemic activity of Asparagus racemosus roots is partly mediated by inhibition of carbohydrate digestion and absorption, and enhancement of cellular insulin action. $\mathrm{Br} \mathrm{J}$ Nutr, 107: 1316-1323.

Huang CN, Wang CJ, Lin CL, Lin HT, Peng CH, 2017. The nutraceutical benefits of subfractions of Abelmoschus esculentus in treating type 2 diabetes mellitus. PLoS One, 7: 12, e0189065.

Kaadan S, Saad B, Sasson Y, Zaid H, 2013. In vitro evaluations of cytotoxicity of eight antidiabetic medicinal plants and their effect on GLUT4 translocation. ECAM, 2013: 549345.

Kaadan S, Saad B, Sasson Y, Zaid H, 2018. Gundelia tournefortii antidiabetic efficacy: Chemical composition and GLUT4 translocation. ECAM, 2018: 8294320.

Kmail A, Lyoussi B, Zaid H, Imtara $\mathrm{H}$, Saad B, 2017. In vitro evaluation of anti-inflammatory and antioxidant effects of Asparagus aphyllus L., Crataegus azarolus L., and Ephedra alata Decne. in monocultures and co-cultures of HepG2 and THP-1-derived macrophages. Pharmacogn Commun, 7: 24-33.
Kmail A, Lyoussi B, Zaid H, Saad B, 2015. In vitro assessments of cytotoxic and cytostatic effects of Asparagus aphyllus, Crataegus aronia, and Ephedra alata in monocultures and co-cultures of HepG2 and THP-1derived macrophages. Pharmacogn Commun, 5: 1-7.

Li C, Zhang BB, 2007. Insulin signaling and action: glucose, lipids, protein. Endotext, [Internet]: Apr 26, 2007.

Liu IM, Tzeng TF, Liou SS, Lan TW, 2007. Improvement of insulin sensitivity in obese Zucker rats by myricetin extracted from Abelmoschus moschatus. Planta Med, 73: 1054-1060.

Mekada K, Abe K, Murakami A, Nakamura S, Nakata H, Moriwaki K, Obata Y, Yoshiki A, 2009. Genetic differences among C57BL/6 substrains. Exp Anim, 14: 141-149.

Negi JS, Singh P, Joshi GP, Rawat MS, Bisht VK, 2010. Chemical constituents of Asparagus. Pharmacogn Rev, 4: 215-20.

Parekh PI, Petro AE, Tiller JM, Feinglos MN, Surwit RS, 1998. Reversal of diet-induced obesity and diabetes in C57BL/6J mice. Metabolism, 47: 1089-1096.

Popovic-Milenkovic MT, Tomovic MT, Brankovic SR, Ljujic BT, Jankovic SM, 2014. Antioxidant and anxiolytic activities of Crataegus nigra Wald. et Kit. berries. Acta Pol Pharm, 71: 279-285.

Saad B, Said O, 2011. Greco-Arab and Islamic Herbal Medicine: Traditional System, Ethics, Safety, Efficacy and Regulatory Issues. Wiley-Blackwell John Wiley \& Sons Inc, 2011.

Saad B, Zaid H, Said O, 2012. Tradition and perspectives of diabetes treatment in Greco-Arab and Islamic medicine. In: Bioactive Food as Dietary Interventions for Diabetes, Ronald RW, Victor RP, Elsevier Science, pp: 319-325.

Saad B, Zaid H, Shanak S, Kaadan S, 2017. Anti-diabetes and AntiObesity Medicinal Plants and Phytochemicals Safety, Efficacy, and Action Mechanisms. (c) Springer International Publishing AG, Chapter 6: $147-174$

Sabitha V, Ramachandran S, Naveen KR, Panneerselvam K, 2011. Antidiabetic and antihyperlipidemic potential of Abelmoschus esculentus (L.) Moench. In streptozotocin-induced diabetic rats. J Pharm Bioallied Sci, 3: 397-402.

Sabitha V, Ramachandran S, Naveen KR, Panneerselvam K, 2012. Investigation of in vivo antioxidant property of Abelmoschus esculentus (L) moench. fruit seed and peel powders in streptozotocin-induced diabetic rats. J Ayurveda Integr Med, 3: 188193.

Senadheera SP, Ekanayake S, Wanigatunge C, 2014. Anti-diabetic properties of rice-based herbal porridges in diabetic Wistar rats. Phytother Res, 28: 1567-1572.

Shin HS, Lee JM, Park SY, Yang JE, Kim JH, Yi TH, 2013. Hair growth activity of Crataegus pinnatifida on C57BL/6 mouse model. Phytother Res, 27: 1352-1357.

Somania R, Singhai AK, Shivgunde $P$, Jain D, 2012. Asparagus racemosus Willd (Liliaceae) ameliorates early diabetic nephropathy in STZ induced diabetic rats. Indian J Exp Biol, 50: 469-475.

Victoria L, Tokarz Patrick E, MacDonald Amira K, 2018. The cell biology of systemic insulin function. Journal of Cell Biol, 217: 22732289.

Zaid H, Antonescu CN, Randhawa VK, Klip A, 2008. Insulin action on glucose transporters through molecular switches, tracks and tethers. Biochem J, 413: 201-215.

Zaid H, Saad B, Mahdi AA, Tamrakar AK, Haddad PS, Afifi FU, 2015. Medicinal Plants and Natural Active Compounds for Diabetes and/or Obesity Treatment. ECAM, 2015: 469762.

Zaid H, Talior-Volodarsky I, Antonescu CN, Klip A, 2009. GAPDH binds GLUT4 reciprocally to Hexokinase-II and regulates glucose transport activity. Biochem J, $419: 475-484$.

Citation: Kmail A, Saad B, Lyoussi B, Said O, Darwish MSA, Kadan S, Sammar S, Qalalweh H, ALbzoor R, AlArda M, Zaid H, 2019. In vitro e valuations of cytotoxicity of Abelmoschus esculentus L, Asparagus a phyllus $\mathrm{L}$. and Crataegus azarolus L. extracts and their effects on $\mathrm{GL}$ UT4 membrane translocation on L6 muscle cells and blood glucose I evels in mice. Adv M ed Plant Res, 7(1): 23-30. 